\title{
TURKISH, BULGARIAN AND GERMAN LANGUAGE MIXING AMONG BULGARIAN MUSLIM ROMA IN GERMANY
}

\author{
Hristo Kyuchukov \\ hkyuchukov@gmail.com \\ University of Silesia in Katowice, Poland
}

Received August 12, 2019; Revised December 1, 2019; Accepted December 22, 2019

\begin{abstract}
The paper discusses language mixing by Muslim Roma migrants from northeastern Bulgaria living in Berlin, Germany. They identify as Turks and in their everyday communication speak mainly Bulgarian and an old northwestern lect of Turkish, in the scientific literature known as Balkanized Turkish. They can speak relatively little German and have demonstrably low proficiency in the language. The paper examines their language mixing as well as the forms of code-switching between Turkish, Bulgarian and German. These linguistic and social phenomena within the Muslim Roma community are analyzed within the framework of several sociolinguistic theories regarding code-switching and bilingualism. The theory of J. Gumperz (1962) about communication matrix is employed as a dynamic frame and patterns of Turkish-Bulgarian, Turkish-German and Turkish-Bulgarian-German are presented and analyzed. The borrowed grammatical categories in the Turkish-Bulgarian-German language contacts involve nouns, verbs, adjectives, adverbs and negations. However, code-switching is used only in communication with other Bulgarians. In communication with Turks from Turkey the lexical borrowings are from German and they use another variety of Turkish. The Muslim Roma in Berlin observed in this study are diverse in their multilingualism. Among them there are speakers of Romani, Bulgarian and Turkish, and of Turkish and Bulgarian, while German, however learned, is their third or fourth language. Differing emergent patterns among second-generation migrants, born or raised from an early age in Berlin, suggest different patterns emerging and such research is a key desideratum.
\end{abstract}

Keywords: Muslim Roma, Bulgarian, code-switching, bilingualism.

Кючуков Хрісто. Проблема змішування турецької, болгарської та німецької мов у болгарських ромів-мусульман у Німеччині.

Анотація. У статті йдеться про явище мовного змішування в мусульманських ромівмігрантів із північно-східної Болгарії, що мешкають у Берліні (Німеччина). Досліджувані ідентифікують себе як турки, й у повсякденному спілкуванні розмовляють здебільшого болгарською мовою та давнім різновидом турецької, що в науковій літературі одержало назву балканізованої турецької. Рівень володіння німецькою мовою у досліджуваних мовців відносно низький. У статті описано феномен змішування мови, а також форми перемикання турецького, болгарського та німецького мовних кодів. Ці лінгвістичні та соціальні явища в мусульманській спільноті ромів аналізуються в межах декількох соціолінгвістичних теорій щодо перемикання коду та двомовності. В основу дослідження покладено теорію Дж. Гамперца (1962) щодо матриці спілкування. У статті представлено та досліджено приклади комбінування турецько-болгарської, турецько-німецької та турецькоболгарсько-німецької кодів. 3'ясовано, що до граматичних категорій, які підпорядковуються феноменові перемикання коду в турецько-болгарсько-німецькому мовному

(C) Kyuchukov, Hristo, 2019. This is an Open Access article distributed under the terms and conditions of the Creative Commons Attribution 4.0 International Licence (http://creativecommons.org/licenses/by/4.0).

East European Journal of Psycholinguistics, 6(2), 50-57. https:/doi.org/10.5281/zenodo.3637716 
варіанті, належать іменники, дієслова, прикметники, прислівники та заперечні конструкції. Однак, перемикання коду простежено тільки під час спілкування з іншими болгарами. Визначено, що у спілкуванні з турками з Туреччини перемикання коду наявне лише між турецькою та німецькою мовами, а також виявлено використання іншого варіанта турецької мови. Роми-мусульмани з Берліна демонструють багатомовність. Серед них носії ромської, болгарської й турецької; турецької й болгарської. Водночас німецька, попри iї знання, посідає третє чи четверте місце за частотністю послуговування. Вивчення мовних патернів мігрантів у другому поколінні, - народжених чи вихованих змалку в Берліні, у своєму розмаїтті видається перспективою подальшого дослідження.

Ключові слова: роми-мусульмани, болгарська мова, перемикання кодів, двомовність.

\section{Introduction}

\section{Berlin \\ 1.1. Sociolinguistic features of the Bulgarian Muslim Roma community in}

The Bulgarian Muslim Roma coming to Berlin usually speak a dialect of Turkish that is known as a Balkanized Turkish with features of Ottoman Turkish. In order to obtain employment from the local Turks in Berlin they seek to learn some additional colloquial Turkish from interaction with Turks in Berlin. This is not a standard Turkish, it is a dialect, but the Bulgarian Muslim Roma are not able to recognize and differentiate this from current modern Turkish. They mistakenly think that this is a form of "standard" Turkish as spoken in Turkey. So, the Turkish spoken by Bulgarian Muslim Roma is a hybrid mixture between the two lects - the Bulgarian variety and the Berlin variety these migrants encounter there, exhibiting forms of diglossia (Nikolskij 1976). In dealings with the local Turkish immigrant population, they state they are Turks, but among themselves they self-identify as Muslim Roma and call themselves "millet" (Turkish, meaning 'nation'). Some, especially of a somewhat older demographic, also speak Romani among themselves.

The Bulgarian Roma also learn as migrants to speak some German. They use it in communication with Germans for whom they work, and their acquisition is haphazard, generally not done systematically through participation in German language courses. Their comprehension ability in German is better than their production abilities and speaking proficiency in German, and they tend to make many phonological and grammatical errors.

However, almost all such Roma families send their children to school, and to after-school activities, because most state that they plan to stay as migrants in Germany. They have their own properties in Bulgaria, they often travel back to Bulgaria, they help the family members who are in Bulgaria providing financial support, but they are planning to stay in Germany. Because of that their children are attending German schools and are highly motivated to be integrated into German society and to learn German fluently.

Their attitude towards the Bulgarian language is different. They use Bulgarian in their everyday communication between members of the community and family members. Bulgarian serves as a communicative tool or sometimes a secret language when they want to hide something from the local Turks. 
Bulgarian Roma live in most of the larger German cities and it is known that the Roma from Pazardzhik are mainly settled in Cologne, the Roma from Shumen are in Düsseldorf, Roma from Plovdiv are in Dortmund, etc., a chaining phenomenon of in-migration where many migrants are attracted to settle where other migrants from their own city of origin have come and settled earlier.

Muslim Roma living in Berlin migrated from northeastern Bulgaria, principally the cities of Varna, Dobrich, Russe, Razgrad and Targovishte and nearby villages. The Berlin districts where Bulgarian Muslim Roma have settled in greater numbers are mainly Spandau, Wedding, Kreuzberg and Neukölln. These are the districts where the Turkish migrants from Turkey live as well, a key factor in attracting Turkish-speaking Bulgarian migrants to settle there. The Muslim Roma in Berlin evince a broad diversity in their multilingualism. Among them there are trilingual speakers of Romani, Bulgarian and Turkish, bilingual speakers of Turkish and Bulgarian, while German, however learned, is their third or fourth language. This also varies among the now emergent and growing second-generation Roma from a migrant background, born and raised in Germany.

The Turkish community in Berlin is not homogeneous. There are speakers of different dialects from across the territory of Turkey. Some have settled there now as third-generation from a migrant background. The Turkish spoken by Turks in Berlin is highly valued $(\mathrm{H})$ and the Turkish spoken by Bulgarian Roma is less (L) valued, according to the terminology of Schiffman (1997). The Bulgarian Muslim Roma speak a variety of Turkish stemming from Ottoman Turkish and to some extent it has almost the same structure as the Gagauz language (i.e. a Bulgarian grammatical structure with Turkish lexicon). In the eyes of most Turks from Turkey, such a lect is deemed to be a very low and corrupted form of Turkish.

\subsection{Theoretical background}

Gumperz (1962) shows that each community has its set of roles in the society, depending on the reticulations of forms of relationship between individuals in the society. The common roles in a community are termed by Gumperz the communication matrix (CM).

The CM differs in communities and depends on the dominant specific social structures present. In some communities the $\mathrm{CM}$ is very complex and the communication behavior of the person is restricted. It depends on traditional and religious rituals, where the behavior and the speech of the person are stable. The differences between the language used for everyday communication and the language used performing certain roles in the society are sometimes very great. People who know the two forms of the same language, the colloquial lect and the official language, rarely use them in the same situation. Usually the role in the society and the forms of the language (the $\mathrm{CM}$ ) are interconnected.

Nikolskij (1976:48) defines the language community as a "stable group of people, which are united by a sign that in intergroup communication they use one form of the language and it does not depend on the situation and the topic of communication". Furthermore, Nikolskij identifies the following forms of diglossia among bilingual speakers (pp. 103-110): 
1. Diglossia, where the speaker knows and uses two dialects or two subdialects.

2. Diglossia, which combines a dialect with other dialectical tools of communication, among speakers of different dialects, which do not understand each other in communication.

3. Diglossia, where the speaker knows the regional dialect and the official language.

4. Diglossia, where the speaker knows the conversational style and the official language.

5. Diglossia, where the speaker is acquainted with different styles of the same official language.

The Bulgarian of Muslim Roma born and raised in Bulgaria is nonetheless not a standard Bulgarian. They speak a vernacular, highly colloquial Bulgarian, and being in a new situation abroad there are numerous influences of Turkish and German on their Bulgarian. In earlier publications Kyuchukov (1995, 1996, 1997, 2007) and Freedman (2003) described the processes of code-switching among different Roma groups. Kocheva-Lefedzhieva (2004, 2017) investigated the mixed language of Bulgarians living in Vienna and found that on the phonological and grammatical level, the Bulgarian speakers have more stable peculiarities, while on the lexical level they exhibit more variant peculiarities. In the mixed language they use on phonological level, Bulgarian characteristics are dominant, while on a lexical level the German characteristics dominate.

Bugarski (2005) discusses the issues of language and ethno-cultural identity. The Muslim Roma have their cultural characteristics as Muslims who are Roma in family origin and basic identity, but in the new situation they identify as Bulgarians and speak vernacular Bulgarian, with differences from the norms of the Bulgarian grammar. The four languages - Bulgarian, Turkish, Romani and German - being in dynamic contact, all share the phenomenon of all languages in contact familiar as "code-switching" and "code-mixing" (Matras, 1990, 2004, 2009; Matras and Tufan, 2007).

\section{Methodology}

The data for this study was collected in two modes:

1. With a hidden tape recorder in public transport, shops and on the streets of Berlin. In the main, a spontaneous colloquial form of speech between Muslim Roma was clandestinely recorded. The speakers were usually in a communication situation with another Bulgarian Muslim Rom individual. Their consent to be recorded was not solicited.

2. The second type of data was collected with unstructured interviews with male and female respondents between the ages of 20 to 50 - a total of five men and five women. The interviews were conducted in the houses of the respondents in an informal situation and conversation. All speech productions are examples of spontaneous speech. They knew they were being recorded and had consented to this. 
All the respondents are from northeastern Bulgaria, from villages and towns around Varna, Dobrich, Targovishte and Russe. The topics of the conversations were stories, dreams, fairy tales, daily life and family problems, their work, etc.

The total number of recordings comprises $11 \mathrm{~h}$. The recorded conversations were transcribed and the sentences with patterns of code-switching identified.

The primary research question here is: What kind of patterns of code-switching between Turkish and Bulgarian exist?

\section{Results}

In their everyday communication the Muslim Roma use the three languages and often they switch between these three languages. Some representative patterns of code-switching are discussed below.

\subsection{Turkish-Bulgarian code-switching}

Examples 1-3 show that the speakers use mainly Turkish but sometimes they borrow some words from Bulgarian, clear lexical borrowings. The lexical borrowings can be adapted to the second language, but often they are used as in the original one. The borrowings in the examples below are from Bulgarian and they are used without any changes. There is no clear idea why sometimes the Bulgarian nouns and verbs are borrowed when the respondents know the Turkish ones. The borrowed categories are: nouns, verbs and adjectives: smyata ('to count'), proverka ('checking, a check'), seriozno ('seriously').

\section{A. Code-switching without changes}

(1) o gündenberi смята yapt1

that day on count do-3sgPT

From that day on s/he counted.

(2) hiç сериозно durmad1

not a serious stay-3 $\mathrm{sgPT}$

He was not serious at all.

(3) kari проверка уapt1

woman checking make-3sgPT

The woman conducted a check.

B. Code-switching with adaptation to Turkish grammatical rules

(4) orda işlerdim işaat işinde cтроителство-da

there workPTense construction work-LOC.

There I worked in construction.

(5) arkadaşlarımlan her zaman дискотека-уа gideriz

friend-with all time disco-to- DAT. go-1pl.PresT

With my friend we go all the time to a disco.

(6) panayira люлка-lar, o dölenme şeyleri geliyler

fair-to swing-pl the turning tings come-pl.

The swings and those things that turn around and around come to the fair. 
The examples from 4-6 shows that the borrowings are mainly nouns and they are adapted to the grammatical rules of Turkish with case endings. In this way the words sound "Turkish". Looking at the syntax one can see that the respondents try to follow the standard Turkish word order in the sentences, where the verb is in the last position $-\mathrm{SOV}$

\subsection{Turkish-German code-switching}

It is interesting that the borrowings from German are also mainly nouns. The Muslim Roma do not know the equivalent words in Bulgarian or in Turkish. Those are lexical items mainly names of institutions, streets which they learned after arriving to Berlin, but there are also cases where they would like to demonstrate that they speak some German, as is shown in Example 7, where the speaker does not use the Bulgarian word vednaga or Turkish word hemen but rather uses the German alterative adverbial sofort.

\section{A. Code-switching without changes}

(7) Ben sofort gittim

I immediately go-3sgPT

I went immediately.

(8) anmeldung üç sene olucak

registration three years will be

It will be three years from my registration.

(9) bizim $u$-bahn bozuk

our metro destroyed

Our metro is destroyed.

As it is shown in the examples 7-9 like the Bulgarian borrowings the German ones are also used without any adaptations to Turkish.

B. Code-switching with adaptation to Turkish grammatical rules
(10) Kiyatverdiler elime
arbeitsamt'an
paper give-3plPT hand
employment agency from-ABL.
They gave me a paper from the employment agency.
(11) Ben sona gidecem jobcentar'a
I after that go-1sgFT jobcenter-to- DAT.
After that I will go to the job center.

In the examples above, the noun Arbeitsamt is used in Ablative case and the noun Jobcenter is used in the Dative from Turkish. So, the rules are the same as in the Bulgarian examples. It does not matter which language the borrowings come from, the rules are the same. The lexeme 'job center' seems to be a loan from English to German and then to in Turkish. 


\subsection{Turkish-German-Bulgarian code-switching}

The most interesting part of the code-switching is when the three languages are used in the same conversation. The following examples show patterns of switching between German-Turkish-Bulgarian (Example 12); Turkish-German-BulgarianGerman-Bulgarian (Example 13); Turkish-Bulgarian-Turkish-German (Example 14). All the switched German words are nouns and the Bulgarian switches are categories such as verbs, negations and adverbials.

(12) Pankstrasse'de

Pankstrasse-at-LOC праим.

do-1plFT karşilaşicas и после чии видим к'во ши meet-1plFT and later will see-1pl.FT what will

We will meet at Pank Street and after that we'll see what we will do.

(13) Lazım termin yapalim. Без tеrтіп няма да стани. needed appointment make-3plFT without appointment will not work We have to make an appointment. Without an appointment it will not work.

(14) Amaneyse, каквото щче да e, yalnız da gidebilirim jobcentar'a but whatever, whatever want to be alone and go-can-1sgCOND. job center- to It doesn't matter, it's not important, I can go alone to the job center.

The examples above show that together with the borrowed lexical items from Turkish or Bulgarian in their everyday life, the respondents switch the languages. For a while the conversation can continue solely in Turkish or Bulgarian, without code-switching. These phenomena are very typical for bilingual/multilingual communities. In previous studies, Giray (2015) showed similar processes among Bulgarian Muslim Roma in Germany.

\section{Discussion and Conclusions}

Looking at the grammatical categories which are borrowed one can conclude that in Turkish-Bulgarian-German language contacts, within the specific CM (Gumperz 1962) investigated in Berlin, there are borrowings of nouns, verbs, adjectives, adverbs and negations.

The new situation in which the Bulgarian Muslim Roma live and work provides them with new strategies for communication. Code-switching/borrowing is one of the ways in which they can express themselves in their everyday communication. However, code-switching is used only when they communicate with other Bulgarians. Communicating with Turks from Turkey they engage in code-mixing only between Turkish and German and use another variety of Turkish.

Fishman (1997) describes a situation which he terms a "perspectival quality of ethnicity". He notes: "Some of those who do not consider themselves X-ians now, may come to consider themselves X-ians in five or ten years from now, or in the next generation" (p. 329). Bulgarian Muslim Roma in Berlin, born and raised in Bulgaria, do not consider themselves Turks, but their children will likely consider themselves as such in years to come. In a conversation with some Bulgarian Muslim 
Roma children 10-12 years old, probably raised in Berlin if not born there, in effect second-generation, I heard them speaking perfect Turkish, and they absolutely think that they are Turks and do not speak any Bulgarian, some are bilingual in Turkish and German. Research on this now emergent second migrant generation within a dynamic migrant $\mathrm{CM}$ is a key desideratum.

\section{References}

Bugarski, R. (2005). Jeziki Kultura [Language and Culture]. Beograd: Biblioteka XX vek.

Friedman, V. (2003). Turkish in Macedonia and beyond. Wiesbaden: Harrasowitz Verlag.

Fishman, J. (1997). Language and ethnicity: the view from within. In F. Coulmas (Ed.) The Handbook of Sociolinguistics. (pp. 327-343). Oxford: Blackwell Publishers.

Giray, B. (2015). Code-switching among Bulgarian Muslim Roma in Berlin. In D. Zeyrek, C. S. Simsek, U. Atasand J. Rehbein (Eds.), Ankara Papers in Turkish and Turkic Linguistics. (pp. 420-430). Wiesbaden: Harassowitz.

Gumperz, J. J. (1962). Types of linguistic communities. Anthropological Linguistics 4(1), 28-40.

Kocheva-Lefedzhieva, A. (2004) Nemski leksikalni elementi v bulgarskite govori [German lexical elements in Bulgarian spoken discourse]. Sofia: Multprint.

Kocheva-Lefedzhieva, A. (2017) Smeseniyat ezik na vienskite bulgari. [The mixed language of Vienna Bulgarians]. Sofia: Bukovica.

Kyuchukov, H. (1995). The Turkish dialects of Muslim Roms (Gypsies) in Bulgaria. Journal of Turkology, 2, 305-307.

Kyuchukov, H. (1996). Etnolingvodidaktika [Ethnolingual didactics]. Sofia: Club '90.

Kyuchukov, H. (1997). Psicholingvistichni aspecti na rannia bilingvizam [Psycholinguistic aspects of early bilingualism]. Sofia. Retrieved from https://knizhenpazar.net/sold_products/books/476519

Kyuchukov, H. (2007). Turkish and Roma children learning Bulgarian. Veliko Tarnovo: Faber.

Matras, Y. (1990). On the emergence of finite subordination in Balkan Turkish. Proceedings of the Fifth International Conference on Turkish Linguistics, SOAS, (17-19 August, 1990).

Matras, Y. (2004). Layers of convergent syntax in Macedonian Turkish. Mediterranean Language Review, 15, 63-86.

Matras, Y. (2009). Language Contact. Cambridge: Cambridge University Press.

Matras, Y. and Tufan, Ş. 2007. Grammatical borrowing in Macedonian Turkish. In Y. Matras and J. Sakel (Eds.), Grammatical Borrowing in Cross-linguistic Perspective. (pp. 215-227). Berlin: Mouton de Gruyter.

Nikolskij, L.B. (1976). Sinhronnaja lingvistika [Synchronous linguistics]. Moscow: Nauka.

Schiffman, H. (1997). Diglossia as a sociolinguistic situation. In F. Coulmas (Ed.), The Handbook of Sociolinguistics. (pp. 205-216). Oxford: Blackwell Publishers. 